\title{
Specialization in nursing management - distance learning in Brazil: I mportance and application from the student perspective
}

\author{
Fabiana Silva Okagawa, Elena Bohomol, I sabel CKO Cunha \\ Nursing School, Federal University of Sao Paulo, Brazil \\ Correspondence: Fabiana Silva Okagawa. Address: Rua Napoleão de Barros, 754. Vila Clementino- São Paulo/SP CEP \\ 04024-002. Telephone: 55-118-241-0373. E-mail: fabiaraxa@hotmail.com
}

Received: January 3, 2012

DOI : $10.5430 /$ jnep.v2n4p56
Accepted: January 31, $2012 \quad$ Published: November 1, 2012

URL: http://dx.doi.org/10.5430/jnep.v2n4p56

\section{Abstract}

Background: This study presents student views on the programmatic content relevant for professional practice, in a distance learning specialization course on Nursing Management.

Methods: This was an exploratory, qualitative study done with 216 nursing students from five states in Brazil. Students' comments were classified according to a theoretical reference on the structure of nursing management knowledge endorsed by Sanna, addressing theoretical and ideological foundations, intervention methods, and resource management practices.

Results: Students expressed that all subjects in the course are important, prioritizing human and political resource management practices, in addition to highlighting leadership and planning themes. The course met the students' expectations regarding both content mastery and applicability.

Conclusions: Distance learning was found to be relevant in national education as a strategy for democratizing knowledge in Brazil, a country of continental dimensions.

\section{Key words}

Distance learning, Nursing management, Education

\section{Introduction}

In Brazil, distance learning (DL) has been in use for more than a century. This type of education began in the country in 1904 , as courses offered by mail, expanding to radio in the 1920s and television in the $1960 \mathrm{~s}^{[1]}$.

The Ministry of Education (MEC) was responsible for the first public policies establishing DL networks intended to train a contingent of high school teachers.

Given the dynamism of information and the expanding use of communication technology such as computers and the Internet, developed over the second half of the twentieth century, DL has undergone extensive and sustained growth, meeting the demand of economically disadvantaged populations. Since 1996, when the Law of Directives and Bases of 
National Education was implemented, undergraduate courses began to be created with priority being given to the poorer regions of the country ${ }^{[2]}$. In 2005, a 30.7\% increase was recorded in higher education institutions requesting registration as a DL course within the MEC education system, totaling 2,329 institutions carrying the DL registry ${ }^{[3]}$. An interest in DL can be seen in nursing, as in other health fields, requiring development of specific courses for these professionals.

To date, there are still few nursing specialization courses offered as distance learning courses in public universities throughout Brazil. One of the first courses, offered in 1998, was on nephrology and approximately 650 specialists have completed the course since then. According to the course coordinator, "The student satisfaction rate is quite high, implying that nursing practice has become relevant for these students before and after the course" ${ }^{\text {[4] }}$. This aspect indicates the possibility of developing other specialization courses in distance-learning mode, prompting the need for investments and professional teaching in this educational field.

Corroborating this statement, a study conducted with university professors in five US states concluded that most respondents frequently used DL and were skilled in teaching tools, in addition to demonstrating that this mode adequately contributes to preparing nurses ${ }^{[5]}$. Due to market demand, competitiveness, and organization sustainability, there are extensive management positions in health services and primary health care, leading to rising opportunities for nurses. Thus, there is a genuine interest in specialization courses for nursing management. Currently, there are 19 in-person specialization courses in this field of knowledge at federal universities distributed throughout the country. Nevertheless, they are too few to serve the demand ${ }^{[6]}$.

Mindful of this movement, the Federal University of Sao Paulo (UNIFESP), in partnership with the Open University of Brazil of the MEC, launched the first version of a DL specialization course in nursing management in 2009.

The course contained programmatic content that reflected the needs of nurses in this new millennium, eminently characterized the process of globalization, technological advances and the consequent competitiveness in the labor market. We live in the era of knowledge and people that hold it are more valued and recognized for being the intellectual capital of organizations.

In this manner, nurses must develop and seek to acquire knowledge necessary for their professional practice, on the basis of needs identified in their work context.

The objective of this present study was to know the student views on the most important programmatic content for professional practice, in a distance learning specialization course on nursing management.

\section{Distance learning course on nursing management}

The course had a 416-hour workload, with a curriculum comprising 12 subjects (Adapting the Learning Environment, Introduction to General Management, Nursing Management, Human Resource Management, Health Information Management, Financial Resource Management, Physical and Material Resource Management, Health Services Assessment, Research Methodology, Trends in Management, Marketing in Health, and Orientation) summarized in a final paper at the program's conclusion ${ }^{[8]}$. For the construction of the foundational curriculum, we chose to use a reference on the structure of knowledge about nursing administration, developed by Sanna ${ }^{[9]}$, in which nine subjects developed in the courses are considered, as shown in Table 1.

These were taken from the framework of the disciplines of Adapting the Learning Environment because it is specific to the setting of the student for the teaching modality; Research Methodology since it permeates all courses in the broad sense in Brazil, and Marketing in Health, which is not knowledge that is delivered in undergraduate nursing courses in the country, however, it was addressed in the specialization course because it is a necessity for the nurse in her professional activities.

This reference presents the following triad: theoretical and ideological foundations, intervention methods, and resource management practices. 
Ideological and Theoretical Foundations include the conclusions of a study on conceptual origin used for understanding and interpreting phenomena related to the process of nursing management work. The following content is included in this block: management theory, philosophy of nursing services, health policy, health legislation, nursing, work, labor market, and fields within nursing.

Regarding the Intervention Methods, Sanna states that they derive from applying the ideological and theoretical foundations and covering four areas of mastery in nursing management: planning, decision making, supervising, and auditing.

Finally, Resource Management Practices addressed experimenting with application of the intervention methods associated to understanding the phenomena involved in Nursing Administration, the specificities of which depend on the resource type. These specificities may be related to human, material, physical, financial, political, and information resources.

The course was 12 months long, starting in April 2009. One of the requirements of the course was that the students complete it with an average grade higher than or equal to seven in all subjects, in addition to turning in an integrative literature review as a final paper and presenting it in person, when the course coordinator visited the location.

A total of 550 places were offered for the 2,841 students who applied. After selection, 495 students enrolled in the course. Students selected were initially distributed in 11 locations, covering five states (São Paulo, Tocantins, Mato Grosso, Pará, and Amazonas). For each location, there was a 50-student maximum, plus two distance-learning tutors and one in-person tutor with specific DL training. The educational strategies used by the students and tutors included discussion forums, self-correcting exercises, and chat, as well as evaluations using multiple-choice, wiki, and a journal. At the end of the course, evaluations were conducted with the teachers, tutors, and students to discuss the content, management skills developed, and suggestions for other versions of the course. In 2010 we developed a second edition of the course, incorporating suggestions from the various assessments completed.

\section{Subjects and methods}

This was an exploratory study using a qualitative approach, focusing on the specific objective of the research project: "Distance education in management for nurses: Challenges, limits, and possibilities," approved by the Ethics and Research Committee of the UNIFESP under number 0898/10.

Of the 495 students enrolled, 216 (43.6\%) participated in this study, spread among eight locations. Upon presentation of their final paper, students were invited to participate in the study and were requested to sign the informed consent form.

At the end of the presentations at each location, the students were invited to consider the program content and its relevance to their everyday practice by answering a questionnaire with the following question: "What content do you consider most important for application in your professional practice? Base your response on day-to-day examples," and an open field was available for their response, without space or time limits.

The investigator numbered the responses in the handouts with Arabic numerals, identifying them with the number preceded by the letter E, referring to specialization (in Portuguese). The responses were next transcribed verbatim into a Microsoft Excel ${ }^{\circledR}$ spreadsheet. After numbering the comments, readings were compiled to allow for understanding and grouping of the ideas to establish classifications for the content. The theoretical reference used for comment classification was based on the structure of nursing management knowledge endorsed by Sanna, which can be seen in Table 1 .

We analyzed all the responses from students and, afterwards, excluded those that did not answer the research question and did not contemplate the frame of reference adopted from the responses. 
Table 1. Relationship between the adopted theoretical framework with the curricular disciplines of the Management Course in Nursing by Distance Learning.São Paulo, 2011.

\begin{tabular}{|c|c|c|c|c|c|c|c|c|}
\hline \multirow{8}{*}{ 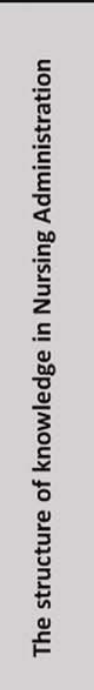 } & $\begin{array}{l}\text { IDEOLOGICAL AND } \\
\text { THEORETICAL } \\
\text { FOUNDATIONS }\end{array}$ & $\begin{array}{l}\text { INTERVENTION } \\
\text { METHODS }\end{array}$ & \multicolumn{5}{|c|}{ RESOURCE MANAGEMENT PRACTICES } & Information \\
\hline & Management Theory & Planning & Dimensioning & Forecasting & Architecture & Finance & $\begin{array}{l}\text { Organizational } \\
\text { Structure }\end{array}$ & Communication \\
\hline & $\begin{array}{c}\text { Philosophy of Nursing } \\
\text { Services }\end{array}$ & Decision Making & Recruitment & Purchase & Design & Budget & Power and Culture & $\begin{array}{l}\text { Record Service } \\
\text { Customer }\end{array}$ \\
\hline & Health Policy & Supervising & Selecting & Storage & Decoration & Costs & $\begin{array}{l}\text { Conflict and } \\
\text { Negotiation }\end{array}$ & $\begin{array}{l}\text { Organizational } \\
\text { Manuals }\end{array}$ \\
\hline & $\begin{array}{l}\text { Health Legislation, } \\
\text { Nursing and Work }\end{array}$ & Auditing & Distribution & Conservation & $\begin{array}{l}\text { Denomination of } \\
\text { legislation and } \\
\text { Magazines }\end{array}$ & Productivity & Leadership & $\begin{array}{l}\text { Administrative } \\
\text { Documents }\end{array}$ \\
\hline & $\begin{array}{l}\text { Labor Market, and Fields } \\
\text { within Nursing }\end{array}$ & & $\begin{array}{l}\text { Performance } \\
\text { Evaluation }\end{array}$ & Distribution & $\begin{array}{l}\text { Customer and } \\
\text { Security } \\
\text { Professionals }\end{array}$ & & Motivation & $\begin{array}{c}\text { Printed and } \\
\text { Electronic Forms }\end{array}$ \\
\hline & & & $\begin{array}{l}\text { Continuing } \\
\text { Education }\end{array}$ & Control & Occupational Risks & & Change & \\
\hline & & & & & & & $\begin{array}{l}\text { Interdepartmental } \\
\text { Relations }\end{array}$ & \\
\hline 들 & $\begin{array}{c}\text { Introduction to General } \\
\text { Management }\end{array}$ & Health Services & Human Resource & Material Resource & Physical Resource & Financial & & Health Information \\
\hline 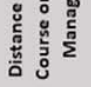 & Trends in Management & Assessment & Management & Management & Management & Management & Nursing IVlanagement & Management \\
\hline
\end{tabular}

To classify the comments, the primary investigator looked for keywords related to the content that could correspond with the elements that make up each block of the triad, performing, in this way, the first classification. This pre-analysis was printed and forwarded to two researchers, connoisseurs of the adopted theoretical framework, for the validation of the classification, characterizing, carrying out the process of investigator triangulation which involves the collaboration of two or more investigators to interpret the data ${ }^{[10]}$. Triangulation uses multiple methods for the analysis of the same fact or phenomenon in a study; in the literature it is also called convergent validity. It is possible to guarantee greater validity of data and outcomes or greater confidence of the researcher in them, and a more profound insertion within the investigated context $^{[11]}$.

Although there were an extensive number of event-rich responses, we chose to present those that would exemplify the structural knowledge elements of nursing management in its multiple scenarios.

No project sponsor had involvement in study design, collection, analysis, data interpretation, writing the report or the final decision to submit our findings for publication.

\section{Results}

The population was characterized by 216 nurses, with ages ranging from 27 to 57 years, with the majority, 53.4\%, in the range of 27 to 32 years. About $54 \%$ of students, who answered the questionnaire, had graduated in nursing from state universities, and $72 \%$ had graduated less than 7 years ago.

Initially the discourses presented related to the first pillar characterized by the ideological and theoretical foundations that involved the manifestations about the importance of administrative theories and the trends in health care system administration. 


\subsection{I deological and theoretical foundations}

When thinking of nursing administration, it is common that aspects related to the resources available at the organization and the skills required by the manager come to mind. However, it should be noted that although the number of responses posted was small, students were able to express themselves about the course, showing which concepts and theories are important contributions for practical use. The students expressed themselves as follows:

"The theories were greatly important to me because at the time I had a management position." (E-166)

“... general management gave me a foundation for daily activities, from planning to executing campaigns, and field work, among others" (E-16)

"General management made me raise questions about my daily challenges in the workplace; as many times, although I like my work sector (Surgical Center), I thought I was inept or unable to manage/administer the place" (E-60)

“... and with the course I finally ... improved my day-to-day skills, because as an assistant nurse, one month ago I was promoted to manager of an outpatient and diagnostic unit of the AME. All of the content was important for my professional practice, from management fundamentals... to the last theme for me...” (E-108)

Following, there are findings mentioned regarding the Methods of Intervention, eminently characterized by the discipline of evaluation of health services for the course, and that were notably expressed in the present study.

\subsection{I ntervention methods}

Nurses are expected to have mastered their management work process by the undergraduate level, using specific intervention methods. These are planning, decision-making, supervising, and auditing. This course highlighted the importance of improving this process, increasing efficiency and effectiveness of nursing care, according to the following comments:

"To start and conduct our work processes, planning is necessary. From there, we can identify the potential barriers that we face day-to-day... I realize that we incipiently plan and because of the course I started to realize and improve my work process, instituting the planning with all of its steps” (S-136)

“... I have implemented a quality system, following the sanitary standards and legislation, among others. By using quality manuals, standard operating procedures...” (S-192)

"We always have to plan, coordinate, and evaluate all activities within the institution in order for us to maintain a quality standard that the institutions are increasingly demanding ” (S-198)

"Result-based quality management, as this subject is already part of my day-to-day profession due to the fact that I am working in a hospital accredited by the ONA and that also has goals to be accomplished ..., which made us go through some everyday practices so then the care provided may improve every day" (S-173)

The broader pillar of the framework, characterized by five subgroups, included the discourses relating to the Resource Management Practices. It can be inferred that students appropriated this knowledge, because they bring practical examples in their responses of how to manage them in their daily lives.

\subsection{Resource management practices}

Resource management practice plays an integral part in the nurse's role within institutions. It is an aspect that is perceived as important, requiring a broad approach in the specialization course. Because numerous comments on the subject were provided, we chose to sub-classify them according to the reference, providing them higher visibility. 


\subsubsection{Human resource management practices}

Human resource management can be found among nursing duties, independent of field or hierarchical level. The course covered content relating to professional selection and recruitment, staffing of care units, continued and permanent education services, assessing individuals’ performance, the importance of interpersonal relationships, and teamwork.

The statements below reflect the importance of this theme for nurses:

“... staffing was very important in discovering that in the hospital where I work at night, the number of nursing professionals is way below the ideal, I helped draft a document with the ideal number and we managed to hire 2 nurses and 4 technicians" (E-196)

“... as I work in nursing coordination, this subject helped me organize my personnel correctly and according to the service required" (E-119)

"The continuing education approach is also important as I can identify demands in the service and help in executing and planning for them" (E-28)

\subsubsection{Material and physical resource management practices}

The course's approach to material resources dealt with content related to forecasting, acquisition, conservation of materials, classification, participation in the standardization committee, and regulating product use, with the status quo being discussed in various forums in different regions of the country. As for the physical aspects, in addition to standards and legislation on the physical structures for health services, the issue of professional and patient safety within these environments was also discussed. The students stressed the importance of this content in their practice, according to the following statements:

“...we have implemented tools for control and storage, considering classification of the material and its validity" $(E-57)$

"... in the structural part, I participated in the construction of the new building, such as positioning and cabinets, doors, archives, clothing, among others...” (E-188)

\subsubsection{Financial resource management practices}

Financial resource management is generally not interpreted as the nurse's responsibility, thus nurses are not generally required to have this specific knowledge. However, the course allowed reflection that this skill needs to be developed by nurses and applied to their practice:

"Financial resource management, often day-to-day, we tend to forget that it is also our responsibility...” (E-69)

"Cost assessment... is very important as I work as an auditor in nursing, I see the problems that hospitals face with this issue. For quality care, reduced costs is important, thus not knowing how to manage them is not satisfactory” (E-1)

\subsubsection{Political resource management practices}

Not always clearly defined and understood, political resources are related to organizational structure, power, and culture; conflict and negotiation; leadership; motivation; change; and interdepartmental relations, according to the adopted reference (9). In the course in question, this content was linked to different subjects, such as nursing management and human resource management. The importance of this approach is noticed in the comments from the students:

"Leadership in nursing made me analyze whether my point of view was correct, as I saw it, where I concluded that there were some issues that I needed to change in my team...” (E-3) 
“... developing leadership skills, as when I started the course I had just graduated, had just been hired by an institution, often did not know how to lead the team... but with dedication and by studying a lot, I could find support in the content offered and applied it adequately to the team. Today, in addition to having a well-structured team and one recognized by the visible change in my behavior...” (E-23)

"Prior to taking the course, I believed that conflicts in the team always had a negative connotation, i.e., bad nursing management, but I could see that conflicts will always exist and that they can be beneficial to the team, as they produce professional growth if adequately addressed" (E-17)

"Content related to interpersonal relationships, such as communication, motivation..., promoted professional and personal growth. This content led to a reflection that health is collectively constructed, where a single professional does not take it on alone..." (E-114)

\subsubsection{I nformation resource management practices}

The importance of information resources permeates nurse training and work. In the course, the following were discussed: telemedicine, information retrieval, information technology, electronic patient records, and health terminology. According to Sanna, aspects that represent information resources are devoted to communication, client records, organizational manuals, administrative and printed documents, and electronic forms. Thus, students expressed the importance of this content:

"Communication-as nurses are leadership figures, able to manage, make decisions, empower their teams, communication is fundamental in the interaction and socialization process, as in my daily routine, where I use it to pass on information and knowledge as I am a teacher and I intend to clarify and orient my students" (E-101)

"Health information provided tools for more cautious assessment, grounded in scientific content" (E-63)

"Health information, which demonstrated the internet's wealth currently and how much content we can acquire using this tool, each passing day occupying more space in our professional lives" (E-66)

“... I worked in a small, non-computerized hospital and recently I started at another larger one, which really helped me in doing the shift schedule, using the systems, in group leadership, in managing material resources...” (E-26)

\section{Discussion}

It can be argued that DL is an important strategy for training professionals in non-degree graduate programs and allows uniform contact with diverse training styles for nursing managers. The present study demonstrated that students had the opportunity to obtain the same information in different regions of Brazil, in addition to allowing them to master the tools provided through the content. The adopted framework permitted the classification of the students' speech encountered in the different programmatic content of the course, identifying that the student also obtained extensive knowledge about nursing administration.

The educational process appropriates concepts and theories for developing critical thinking, where students perceived its importance, being interpreted through the importance of understanding administrative theories. These theories allow us to know the administrative process of diverse Brazilian health institutions, how they are influenced, and which problems are encountered in the daily work of nursing managers ${ }^{[12]}$.

It is noteworthy that discussions on philosophy of nursing services and health politics were not reported, although they are necessary for these professionals' practice. Philosophy of nursing services not only guides the way professionals relate to 
the patient, family, community, and each other, but has significance in their professional practice. These issues deserve consideration by organizers of the course because they are highlighted in stimulating critical thinking and because philosophy and policies influence the way to act. The weakness of this subject can be seen in a study conducted at public hospitals in Brasilia, Brazil, where nurses were not concerned about the philosophy of nursing services as guidelines to prioritize nursing activities, guiding individuals in the institution's values ${ }^{[13]}$.

Intervention methods, according to Sanna, were emphasized in the present study, since they are considered necessary for equipping the nurses, including Planning. Planning has been considered a basic requirement for effective management of a service. In the process of working in nursing management this activity is intended solely for the nurse. The appropriation of this tool is a necessary, legal responsibility of the profession, to obtain and care with quality and safety for one's clients ${ }^{[14]}$.

The course covered Balanced Scorecard use as a trend among institutions, a methodology that helps organizations reflect their balanced and aligned business strategy for objectives, indicators, goals, and action plans that direct behavior and performance.

It is denoted by the comments, that the course was important for professionals who work in quality management, as this issue becomes increasingly more present in organizations in Brazil and throughout the world. Individuals are increasingly aware of their rights and consequently are more demanding, requiring safe and quality health care. Therefore, institutions seek to evaluate their services and tailor them to the clients' needs, as nurses are closely linked to the institution's quality management. Studies indicated the importance of these professionals reflecting on their actions in pursuit of quality care and using the team to pursue hospital accreditation ${ }^{[15]}$.

Managerial practice is supported in students' comments in respect to the knowledge needed for resource management. We observed that there are a great interest in doing research related to human resources in nursing (training, staffing of the nursing team, selection of personnel, among others) while other areas do not raise the same interest ${ }^{[16]}$. The preoccupation with human resources in nursing can be attributed to frequent necessities in their daily lives, such as for example the failure in the dimension of staffing and the deficiency of continuing education in the workplace ${ }^{[17]}$. It is known that the adequate staffing of the nursing team and the qualification of these professionals are implicated in positive outcomes in the care of clients, highlighting the reduction of hospitalization time, and the prevention of death in critically ill patients to the increase in patient safety ${ }^{[18,19]}$.

Knowledge of how to manage these other physical, material, and financial resources, although not always in professionals' daily lives, is important for empowering nurses as managers, since it allows them to interact with the working environment and to control costs related to nursing care, thus achieving balance between quantity, cost, and quality. The nurses pointed out content related to financial resources, inferring that rising health costs in Brazil and the world, awakened the urge to acquire specific expertise to manage these. Already as far back as 1982, the World Health Organization indicated the nurses as the professionals with the greatest potential, in the health area, to ensure the management of costs, which are responsible for $40-50 \%$ of the revenues of hospitals ${ }^{[20]}$.

According to the reference, political resources constitute a skill needed for nursing practice, and the leadership theme was the political issue most commented on by students. Studies have revealed the importance of this skill in nursing, indicating that it is required in the competitive labor market, which may contribute to successful nursing in organizations ${ }^{\text {[21] }}$. Yet, nursing managers and supervisors in public and private institutions within the country point to leadership as the most important competency for their practices and that it should be continuously improved, and both professionals and institutions should mobilize efforts and dedication for their development ${ }^{[22]}$.

Currently, we are living in an era of fast-paced transformations and more complex settings in which organizations need to search for new management rationales to face competitiveness, and the communication processes must have an effective 
and skilled foundation for organizations to act and exist ${ }^{[23]}$. The course allowed the debate on the communication theme as a means for effective dialogue between nurses and the users of the health system or other members of the organization's team. However, students did not relate effective communication with patient safety, a finding that attracts attention, since numerous studies indicate the efficacy of communication as being effective in reducing risks to patients, and it is considered a prerequisite for hospital accreditation organizations such as Joint Commission International ${ }^{[24,25]}$.

This study demonstrated the importance of nursing management in its different areas, highlighting that each student has specific needs to be met with the course content.

\section{Limitations}

The findings of this study should be interpreted with caution, considering two key limitations. The first refers to the actual reference, categorized by Sanna, which excluded content such as marketing in health, research methodology, and professional skills expressed by students' statements but not categorized in this study. The second is related to the figure that represents the relationship between the theoretical framework and the disciplines of the course. This relationship was presented didactically for clarification of the reader, considering the dominant theme (central) of the disciplines of the course and correspondence with the knowledge that comprises the theoretical framework, however the disciplines are more comprehensive than the relation proposed in this study. It should be considered, even discreetly that they permeate other areas of the structure of knowledge about nursing administration.

\section{Conclusion}

We believe that the course met the students' expectations, since numerous comments demonstrated content mastery and applicability. Students generally expressed satisfaction in relation to the overall course, emphasizing its importance, using practical examples from their daily lives.

The discourses about the programmatic content pointed out the development of knowledge essential for coping with difficulties experienced in the daily work of nurses, demonstrating, including, positive repercussions arising from the acquisition of new knowledge and modifications of the realities in which these professionals found themselves inserted.

The EAD highlighted its importance in the teaching of nursing management in Brazil since students originating from diverse locations across the country and inserted into different scenarios of action could express the importance of information obtained in the course to develop their practice.

\section{Acknowledgement}

We would like to thank the subjects who participated in the study.

\section{References}

[1] Vieira RRC, Peres HHC. A panorama of Brazil’s online nursing teaching. Rev Esc Enferm USP. 2008; 42(2): $298-04$. PMid:18642742

[2] Giolo J. Distance education: the tensions between public and private. Educ Soc. 2010; 31(113): 1271-98.

[3] Moran JM. Evaluation of higher education by distance learning in Brazil [Internet]. 2009. Available from: http://www.eca.usp.br/prof/moran/avaliacao.htm

[4] Barbosa D. On-line specialization course in nephrology nursing [Internet]. 2011. Available from: http://www.virtual.unifesp.br/home/card.php?obj=56

[5] Nguyen DN, Zierler B, Nguyen HQ. A survey of nursing faculty needs for training in use of new technologies for education and practice. J Nurs Educ. 2011; 50(4): 181-9. PMid:21117532 http://dx.doi.org/10.3928/01484834-20101130-06 
[6] Meneses AS, Sanna MC. Accessibility and content of electronic information about specialization courses in nursing administration. Rev Esc Enferm USP. 2011; 45(2): 356-62. http://dx.doi.org/10.1590/S0080-62342011000200008

[7] Cunha ICOK. Aquisition of the competencies of health management. In: Balsanelli AP, Cunha ICKO, Feldman LB, Ruthes RM. Competências Gerenciais: desafio para o enfermeiro. 2.ed. São Paulo: Martinari. 2011; 23-5.

[8] Cunha ICKO, Alves VLS, Graziosi MES, Parra JFG. Student manual. Specialization course in nursing management I [Internet]. 2010. Available from: http://www.uab.unifesp.br/file.php/71/Informacoes_sobre_o_curso/Manual_aluno_2010_final.pdf

[9] Sanna MC. The structure of knowledge in nursing administration. Rev Bras Enferm. 2007; 60(3): 336-8. PMid:17684915 http://dx.doi.org/10.1590/S0034-71672007000300017

[10] Driessnack M, Sousa VD, Mendes IAC. An overview of research designs relevant to nursing: Part 3: Mixed and multiple methods. Rev. Latino-Am. Enfermagem. 2007; 15(5): 1046-9. PMid:18157461 http://dx.doi.org/10.1590/S0104-11692007000500025

[11] Teixeira JC, Antonialli LM, Nascimento MCR. Profiles of studies in administration that used methodological triangulation: an analysis of the annals of Enanpad from 2007 to 2009.] XIII Seminário em Administração. 2010 Sep 9-10; Brasil.São Paulo.

[12] Kurcgant P. Theories of administration and the services of nursing. In: Administração em Enfermagem. Kurcgant P. ed. Pedagógica e Universitária: São Paulo-SP. 1991; 5-12.

[13] Costa RA, Shimizu HE. Study of tasks performed by nurses in a teaching hospital. Rev Esc Enferm USP. $2006 ; 40$ (3): $418-26$. PMid:17094327

[14] Parra JFG, Alves VLS. Planning and organization. In: Balsanelli AP, Cunha ICKO, Feldman LB, Ruthes RM. Competências Gerenciais: desafio para o enfermeiro. 2.ed. São Paulo: Martinari. 2011; 193-9.

[15] Lima SBS, Erdmann AL. Nursing role during accreditation process of an emergency service. Acta Paul Enferm. 2006; 19(3): 271-8. http://dx.doi.org/10.1590/S0103-21002006000300003

[16] Ciampone MHT, Felli VEA, Castilho V, Kurcgant P. The production of knowledge in the field of Management of Nursing services in the Graduate Program in Nursing. Rev Esc Enferm USP. 2005; 39(spe): 535-43.

[17] Enfermagem PT. Portuguese receive less than two hours of nursing care [Internet]. Available from: http://www.enfermagempt.org/2011/01/portugueses-recebem-menos-duas-horas-de.html

[18] Kutney-Lee A, Aiken LH. Effect of nurse staffing and education on the outcomes of surgical patients with comorbid serious mental illness.Psychiatr Serv. 2008; 59(12): 1466-9. PMid:19033176 http://dx.doi.org/10.1176/appi.ps.59.12.1466

[19] Kane RL, Shamliyan T, Mueller C, Duval S, Wilt TJ. Nurse staffing and quality of patient care. Evid Rep Technol Assess (Full Rep). 2007; 151:1-115.

[20] Francisco IMF, Castilho V. Insertion of cost teaching in the discipline of administration applied to nursing. Rev Esc Enferm USP. 2006; 40(1): 13-9. http://dx.doi.org/10.1590/S0080-62342006000100002

[21] Gaidzinski RR, Peres HHC, Fernandes MFP. Leadership: continuous learning in the management in nursing. Rev Bras Enferm. 2004; 57(4): 464-6. PMid:15603487 http://dx.doi.org/10.1590/S0034-71672004000400015

[22] Cunha ICKO, Furukawa PO. Profile and competencies of nurse managers at accredited hospitals. Rev. Latino-Am. Enfermagem. 2011; 19(1): 106-14. http://dx.doi.org/10.1590/S0104-11692011000100015

[23] Cardoso OO. Business communication versus organizational communication: new theoretical challenges. Rev Adm Pública. 2006; 40 (6): 1123-44.

[24] Leonard M, Graham S, Bonacum D. The human factor: the critical importance of effective teamwork and communication in providing safe care. Qual Saf Health Care. 2004; 13 Suppl 1: 85-90. PMid:15465961 http://dx.doi.org/10.1136/qshc.2004.010033

[25] Lyndon A, Zlatnik MG, Wachter RM. Effective physician-nurse communication: a patient safety essential for labor and delivery. Am J Obstet Gynecol. 2011; 205(2): 91-6. PMid:21640970 http://dx.doi.org/10.1016/j.ajog.2011.04.021 